\title{
PRESIDENTIAL PENDULUMS IN FINANCE
}

\author{
Christina Parajon Skinner*
}

This Article explores the role of the executive branch, when driven by the President, in deregulating the financial system. While administrative law formally requires that financial regulation derive from notice-and-comment rulemaking, Presidents of the past two administrations have made novel use of an array of executive branch tools to effectively regulate and deregulate the financial services industry. This Article claims that such a shift away from formal administrative law rulemaking processes toward presidentially driven deregulation has implications for the overall stability of the financial system. Specifically, this Article suggests that a President's ability to unilaterally and informally deregulate (and, by extension, regulate) the financial sector can make regulatory cycles more frequent. In turn, the financial cycle may become shorter, steeper, and more severe. If Presidents push and pull on the financial sector, the pendulum of economic activity can swing sharper and faster than it has before-with accompanying repercussions for businesses and households in the real economy.

I. Introduction

II. The Pendulum Problem .536

A. Political-Economy, Public Choice, and the Pendulum

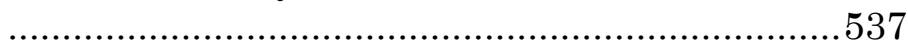

B. Past Pendulums...................................................539

III. Loosening the Regulatory Levers ................................545

A. Legislative Inertia .................................................55

B. Presidential (De)regulation in Action ....................549

1. Agency Guidance .............................................549

2. Enforcement Priorities ........................................551

* Assistant Professor, Legal Studies and Business Ethics Department, The Wharton School of the University of Pennsylvania. Roberta Romano and John Armour provided generous feedback on an earlier version of this Article. Jen Yong provided excellent research assistance. 
3. Agency Priorities 555

4. Staffing Decisions

5. Rule Delay

6. Information Signaling 561

7. Public Pressure

IV. From Regulatory Cycles, to Financial Cycles 566

A. Feedback Loops: An Overview ...........................566

B. Feedback Loops: The Details .............................569

V. Conclusion

\section{INTRODUCTION}

As renowned bank regulation expert Eugene Ludwig remarked in the fall of 2018, financial "deregulation is in the wind." ${ }^{1}$ Deregulating various components of the financial services sector has been a key priority for the Trump Administration. In fact, one week after his inauguration, President Trump promised to "do a big number on Dodd-Frank" - the key piece of legislation that Congress passed in response to the 2008 global financial crisis (the "financial crisis" or "the crisis"). ${ }^{2}$

1 Eugene Ludwig, Warning: The Deregulatory Mood Can't Last Forever, AM. BANKER (Oct. 31, 2018), https://www.americanbanker.com/opinion/warning-the-deregulatory-mood-cant-last-forever?tag=00000153-1968d44a-a15f-d96c413e0000 [https://perma.cc/32CT-PY3B]; see also Chris Flood, 'Bonfire of Regulations' Feared Under New SEC Boss, Fin. Times, (Feb. 3, 2017), https://www.ft.com/content/9ef7ccee-de5a-11e6-86acf253db7791c6 [https://perma.cc/8CQ5-W9ZR].

2 Dodd-Frank Wall Street Reform and Consumer Protection (DoddFrank) Act, Pub. L. No. 111-203, 124 Stat. 1376, 1570 (2010). See Glenn Thrush, Trump Vows to Dismantle Dodd Frank 'Disaster', N.Y. TIMEs (Jan. 30, 2017), https://www.nytimes.com/2017/01/30/us/politics/trump-doddfrank-regulations.html?_r=0 [https://perma.cc/NT7K-2UQF]. President Trump so remarked while signing an Executive Order requiring that, for every new regulation issued, "at least two prior regulations be identified for elimination.” Exec. Order No. 13,771, 82 Fed. Reg. 9,339 (Feb. 3, 2017). The Order applies to executive agencies, but will likely impact or influence independent financial regulatory agencies as well. For example, even though the OCC is technically an "independent agency," a new Comptroller could undertake any range of stalling tactics, or attempt to influence politically appointed colleagues, to undermine the Dodd-Frank Act. Even the Federal 
For most of the United States' history, the legislature has tightened or loosened constraints on the financial system via statute and the power it delegates to regulatory agencies. In recent years, however, that traditional allocation of authority has shifted from Congress to the executive branch. To be sure, Presidents have often played some part in shaping or influencing financial legislation. But Presidents since the crisis can now turn the dial up - or down-on financial regulation.

The presidential practice involves a range of informal-or novel use of existing - tools to adjust regulatory constraints on the financial services industry. These practices include, for example, the issuing of agency guidance; delaying previously issued final rules; adjusting agency staffing; altering enforcement priorities and resources; and signaling to markets through various forms of public statements and white papers. These practices effectuate deregulation by reducing the practical constraints imposed by regulations-or in some cases, by removing or impeding the constraints completely. ${ }^{3}$

This Article describes that phenomenon and then points to some unintended costs that may follow from shifting regulatory power from Congress to the President. Because the degree to which the financial sector is regulated has a direct impact on the amount of credit it supplies, presidential deregulation can accelerate the ebb and flow of the financial cycle. As such, presidential pushing and pulling of regulation can increase the frequency of the financial cycle.

That is an outcome worth avoiding. ${ }^{4}$ Each financial cyclewith its booms and busts-entails various social and economic

Reserve Board - though not subject to congressional appropriations-has voluntarily complied with the executive's broad order for agency hiring freezes. See David Harrison \& Kate Davidson, Fed to Alight Itself with Government Hiring Freeze, WALL. ST. J. (Jan. 27, 2017), https://www.wsj.com/articles/fed-to-align-itself-with-government-hiring-freeze-1485475194 [https://perma.cc/TP3F-P5B4]; see also Exec. Order, 82 Fed. Reg. at 9,339.

3 See Jonathan H. Adler, Hostile Environment, NAT'L REV. (Sept. 27, 2018), https://www.nationalreview.com/magazine/2018/10/15/hostile-environment [https://perma.cc/CH3A-4Y97].

4 Historically, financial cycles seem to occur about every five to ten years. See Ray Dalio, Principles for Navigating Big Debt Crises 14-16 (2018); see also BANK InT'L SETtlements, 84TH ANNUAL REPort 68 (2014). 
costs. Economic downturns are particularly painful for the businesses and households in the real economy, and governments often spend considerable resources in executing monetary and fiscal policies to help the economy recover. Accordingly, presidential action that precipitates these cycles can add stress to the financial system and the public fisc. ${ }^{5}$

In making these descriptive and normative claims, the Article takes forward existing legal scholarship on the political economy of financial regulation and deregulation. ${ }^{6}$ While other scholars have studied the phenomenon whereby financial regulation responds cyclically to political forces, this Article studies how presidential action specifically can cause the

However, other assessments suggest that financial cycles have historically occurred around every sixteen years. See Claudio Borio, The Financial Cycle and Macroeconomics: What Have We Learnt?, 45 J. BANkING \& Fin. 182 (2014).

5 See Christina Parajon Skinner, Nonbank Credit, 9 Harv. Bus. L. REV. 149, 160 (2019).

6 See, e.g., John C. Coffee, Jr., Political Economy of Dodd-Frank: Why Financial Reform Tends to be Frustrated and Systemic Risk Perpetuated, 97 CoRnell L. REV. 1019, 1059 (2012); Roberta Romano, The Sarbanes-Oxley Act and the Making of Quack Corporate Governance, 114 YALE L.J. 1521, 1591 (2005) (“[C]ongressional lawmaking in times of perceived emergency offers windows of opportunity to well-positioned policy entrepreneurs . . . when there is little time for reflective deliberation."). Professor Coffee sets out a theory of a regulatory "sine curve" to explain the "intensity of the oversight exercised by financial regulators." See Coffee, supra note 6, at 1029. By that phrase, he means

both that (1) regulatory oversight is never constant but rather increases after a market crash and then wanes as, and to the extent that, society and the market return to normalcy, and (2) the public's passion for reform is short-lived and the support it gives to political entrepreneurs who oppose powerful interest groups on behalf of the public also quickly wanes.

Coffee, supra note 6, at 1029. See also Kathryn Judge, Regulation and Deregulation: The Baseline Challenge, 104 VA. L. REV. OnLINE 101 (2018); David Zaring, The Federal Deregulation of Insurance, 97 TEx. L. REv. 126, 128 (2018) (arguing that agencies, as opposed to Congress or the executive, are the optimal institutional actors for deregulating the insurance market and institutions). 
regulatory pendulum to swing more frequently than it has historically.

The Article proceeds in five Parts. Part II provides some historical, empirical, and theoretical background on regulatory cycles. Primarily, this Part discusses the way in which regulatory cycles have previously unfolded-that is, through legislation and formal agency rulemaking. Part III turns to a descriptive analysis of how the President has driven deregulation over the past several years. Mainly, this Part focuses on examples of presidentially driven deregulation which have happened between 2017 and 2020. It also discusses presidentially driven regulation under the prior administration, albeit to a lesser extent. While this Part is agnostic on the merits of any particular regulation or deregulation, it is critical of this procedural mode of deregulation insofar as it stands to increase macro financial stability risks.

Part IV then makes the link between presidentially driven (de)regulation and the financial cycle, thereby connecting the Article's administrative law claims to its economic ones. Part $\mathrm{V}$ offers some modest policy prescriptions for checking or constraining presidentially driven (de)regulation, such as statutory sunsets or safety valves; requirements for cost-benefit analyses; or more refined limits on delegation.

\section{THE PENDULUM PROBLEM}

That financial regulation swings like a pendulum-or, stated differently, comes in cycles-is not a new phenomenon; for a century, financial regulation has ebbed and flowed with political-economy winds. ${ }^{7}$ Congress drove these cycles by enacting legislation in response to the public pressure that often followed a crisis or scandal. Regulatory agencies then implemented the rules fleshing out that legislation. Eventually, when public attention on the problems faded, Congress would

7 See, e.g., Jihad Dagher, Regulatory Cycles: Revisiting the Political Economy of Financial Crisis, Vox EU (Mar. 22, 2018), https://voxeu.org/article/regulatory-cycles-revisiting-political-economy-financial-crises

[https://perma.cc/X9ZD-ZWH6] (concluding from a study of ten episodes of boom and bust cycles that regulatory cycles are a "recurring feature since the early days of finance and across countries"). 
respond to private sector entreaties for regulatory unburdening. ${ }^{8}$ And the agencies followed suit.

But over the past decade a new pattern has emerged-the President, rather than Congress, drives regulation and deregulation. This Part gives background on the regulatory pendulum problem by providing some history on past regulatory cycles. It contextualizes these cycles with public choice and political economic theory.

\section{A. Political-Economy, Public Choice, and the Pendulum}

There is ample scholarship discussing the public choice (i.e., political economy) reasons why financial regulation waxes and wanes in cyclical fashion. Both Professor John Coffee and Professor Roberta Romano have argued that major pieces of financial legislation are crisis-driven; that is, the manifestation of an elected congress responding to public outcry. ${ }^{9}$ These two scholars have differing views on the legitimacy of the statutory result; but still, they agree that much of financial regulation is driven by political economy pressures.

There are deep theoretical roots to that line of reasoning. Scholars of regulation have long considered the self-interested motivations of politicians in crafting legislation. For example, Gary Becker and Sam Peltzman have urged that politicians cater to industry interests in order to secure political and professional advantages. ${ }^{10}$ Accordingly, when industry desires

8 See Coffee, supra note 6.

9 See id.; Romano, supra note 6.

10 This became known as the "normative theory of positive analysis" which later evolved into the New Haven/Progressive School of economic regulatory theory. See Sam Peltzman, The Economic Theory of Regulation After a Decade of Deregulation, in Brookings Papers on Economic Activity: MiCROECONOMICS 1 (1989). Meanwhile, on the efficiency side of the theoretical ledger, Joseph Stiglitz has written that "[o]nly under ideal circumstances may individuals, acting on their own, obtain 'pareto efficient' outcomes ... . In the absence of these ideal circumstances, there exist government interventions that can potentially increase societal efficiency and/or equity." Joseph Stigliz, Regulation and Failure, in New Perspectives on Regulation 11, 11 (2009); see also Johan den Hertog, Review of Economic Theories of Regulation (Utrecht Sch. of Econ. Discussion Paper Series, Paper No. 10-18, 
regulation (because, for example, regulation reduces competition), regulation that serves those interests is likely to follow. ${ }^{11}$ Conversely, where deregulation can benefit an industry-because there is a buildup of deadweight loss that can be captured from the regulation's removal-then, again, deregulation is likely. ${ }^{12}$

As such, we can expect to see major pieces of financial reform legislation following a major crisis. We can also expect a subsequent period of deregulation when demands for regulatory efficiency escalate and concerns about excessive risk-taking die down. Indeed, as one piece of IMF research sets out,

financial booms-and risk-taking during these episodes-were often amplified by political regulatory stimuli, credit subsidies, and an increasing light touch approach to financial supervision. Financial crises led to a massive regulatory backlash, which sometimes suffocated finance. The regulatory response can be best understood in the context of the political ramifications of such crises. ${ }^{13}$

To illustrate more concretely, the following Sections provide some abbreviated examples of past regulatory cycles in the U.S., which appear to have been driven by these kinds of political economy pressures. One main purpose of setting out these examples is to highlight the role that Congress has played as the primary driver of past financial regulatory cycles.

2010), https://www.uu.nl/sites/default/files/rebo_use_dp_2010_10-18.pdf [https://perma.cc/C28S-MN3M].

11 See, e.g., Peltzman, supra note 10, at 38 (predicting regulatory intervention "as long as an industry is viable").

12 See Peltzman, supra note 10, at 21. Notably, Peltzman explains the deregulation of the savings and loan industry in the 1980s in such terms. Initially, Peltzman states, regulation "served some important organized interest groups-the commercial banks and the S\&Ls and their allies, the homebuilding industry.... [R] egulation of bank entry, state restrictions on branching, and prohibition of S\&L competition for demand deposits all acted to restrain the competitive rent dissipation." Id. at 33-34. But "[b]y 1970 it was clear that rate regulation on large time deposits was no longer viable, and these were deregulated." Id. at 34 .

13 Dagher, supra note 7. 


\section{B. Past Pendulums}

Perhaps the first meaningful regulatory cycle in U.S. financial markets followed the Great Depression of the 1930s. Public outcry over the various frauds and abuses associated with the Great Depression ${ }^{14}$ propelled Congress to pass the Securities Act of $1933^{15}$ and the Securities Exchange Act of 1934. ${ }^{16}$ Major banking legislation also followed in the Banking Act of 1933 ("the Glass-Steagall Act"), ${ }^{17}$ and the Banking Act of $1935 .{ }^{18}$ While the majority of these reforms stood over time, several of their key components were peeled back in later decades. Consider two important examples.

The Depository Institutions Deregulation and Monetary Control Act of 1980 ("DIDMCA") removed the interest rate caps imposed by Regulation Q. ${ }^{19}$ Regulation Q, which was put in place by section 11 of the Glass-Steagall Act, had capped the interest rates that commercial banks could pay customers on their deposits. ${ }^{20}$ Interest rate caps were intended to prevent interest rate wars between banks, but were later viewed as restraining banks from competing with thrifts or the newly invented money market mutual funds. ${ }^{21}$

14 See, for example, revelations made in connection with the Pecora Commission. See S. REP. No. 73-1455 (1934).

15 Securities Act of 1933, Pub. L. No. 73-22, 48 Stat. 74 (codified as amended at 15 U.S.C. $\S \S 77 a-77$ aa (2018)).

16 Securities Exchange Act of 1934, Pub. L. No. 73-291, 48 Stat. 881 (codified as amended at 15 U.S.C. $§ \S 78 a-78 q q(2018)$ ).

17 Banking Act of 1933, Pub. L. No. 73-66, 48 Stat. 162 (codified as amended in scattered sections of 12 U.S.C.).

18 Banking Act of 1935, Pub. L. No. 74-305, 49 Stat. 684 (codified as amended in scattered sections of 12 U.S.C.).

19 Depository Institutions Deregulation and Monetary Control Act of 1980, Pub. L. No. 96-221, 94 Stat. 132. Here a qualifier seems necessaryinterest rate caps are antithetical to competition and efficiency. The point here is simply that the removal of a regulation was wholesale.

20 Banking Act of $1933 \S 11$; Payment of Interest on Deposits, 12 C.F.R. $§ 217$ (1938).

21 For an interesting history, see Norman Strunk \& Fred Case, Where Deregulation Went Wrong: A Look at the Causes Behind SaVINGS AND LOAN FAILURES IN THE 1980s 2, 14 (1988); see also Fred E. Case, Deregulation: Invitation to Disaster in the S\&L Industry, 59 FoRDHAM L. 
Later, the Financial Modernization Act of 1999 ("the Gramm-Leach-Bliley Act") repealed certain provisions of the Glass-Steagall Act, radically altering the financial system. For one example, section 20 of the Glass-Steagall Act prohibited banks in the Federal Reserve System from affiliating with any business "engaged principally" in underwriting and dealing securities. ${ }^{22}$ By repealing this section, the Gramm-LeachBliley Act enabled some financial institutions to expand their businesses into many simultaneous areas of financial services, thus growing to become too big to fail. ${ }^{23}$

Just a few years later, Congress pushed and pulled the pendulum of securities regulation. In response to the corporate accounting scandals of the early 2000s (involving Enron, WorldCom, and Arthur Anderson) ${ }^{24}$ Congress enacted the Sarbanes-Oxley Act of 2002 ("SOX"). ${ }^{25}$ Squarely aiming at the conduct in those scandals, SOX set out to improve corporate transparency through increased disclosure and reporting requirements. ${ }^{26}$ But the requirements of SOX strained the markets. Small start-ups struggled with the new costs associated with raising capital through a public offering. ${ }^{27}$

REV. S93 (1991); Alvin C. Harrell, Book Review and Commentary: Where Deregulation Went Wrong, 42 Consumer FIn. L.Q. REP. 216 (1998) (reviewing STRUnK \& CASE, supra note 21).

22 Banking Act of $1933 \S 20$, repealed by Gramm-Leach-Bliley Financial Modernization Act, Pub. L. No. 106-102, 113 Stat. 1338 (1999) (codified as amended in scattered sections of 12 U.S.C.).

23 See Saule T. Omarova, The Merchants of Wall Street: Banking, Commerce, and Commodities, 98 MinN. L. REv. 265, 279-80 (2013).

24 Data gathered by Robert Prentice shows that in response to these scandals, the Dow Jones Industrial Average dropped twenty-five percent, the Standard \& Poor's index dropped more than forty percent, and the NASDAQ index dropped more than seventy percent. Robert Prentice, Sarbanes-Oxley: The Evidence Regarding the Impact of SOX 404, 29 CARDOZO L. REV. 703, 712 (2007).

25 See Romano, supra note 6, at 1544.

26 The measures undertaken in the legislation thus intended "to protect investors by improving [the] accuracy and reliability of corporate disclosures made pursuant to the securities laws." Sarbanes-Oxley Act of 2002, Pub. L. No. 107-204, 116 Stat. 745, 745.

27 See, e.g., Marius Meland, Faced With SOX, Some Companies Go Private, LAw360 (Jan. 25, 2006), https:/www.law360.com/articles/5107/faced- 
Other parts of SOX were universally disliked for compelling extremely expensive disclosures. ${ }^{28}$ Specifically, section 404(b) required that an outside auditor "attest to, and report" on companies' controls, and report on management teams' assessment of those controls, as set out annually in their SEC

with-sox-some-companies-go-private [https://perma.cc/Q39U-5WJ8]; Smrity Prakash Randhawa, The Sarbanes-Oxley Act and Small Public Companies 38 (June 15, 2009) (unpublished manuscript), https://msbfile03.usc.edu/digitalmeasures/srandhaw/intellcont/Research_paper_SPR-1.pdf [https://perma.cc/L9AT-V3YS].

28 A 2005 study of Fortune 500 companies, for example, found that average audit fees increased by $\$ 2.3$ million between 2003 and 2004 -an increase the study found to be "primarily attributable" to the new audit requirement in section 404(b). See Susan W. Edridge \& Burch T. Kealey, SOX Costs: Auditor Attestation Under Section 404 22-23 (June 19, 2005) (unpublished manuscript), http://citeseerx.ist.psu.edu/viewdoc/download?doi=10.1.1.516.5992\&rep=rep1\&type=pdf [https://perma.cc/CDK4XAWB]. The same study found that smaller companies were much more significantly impacted by these section 404(b) costs than were larger companies-both because smaller companies had less resources to dedicate to internal controls, and because smaller, but quickly growing, firms would likely have more difficulty updating their control systems. See id.; see also David S. Addington, Heritage Found., Congress Should Repeal or FiX Section 404 of the Sarbanes-Oxley Act To Help Create Jobs (2011), http://thf_media.s3.amazonaws.com/2011/pdf/wm3380.pdf

[https://perma.cc/Y6DV-4YEN] (arguing that the costs of section 404 appear to outweigh its benefits); Biance Fischer et al., Evaluating SOX Section 404: Costs, Benefits, and Earnings Management, 3 ACRN J. Fin. \& RISK PERsP. 43, 47 (2014). Cf. Dhammika Dharmapala, Estimating the Compliance Costs of Securities Regulation: A Bunching Analysis of Sarbanes-Oxley Section 404(B) (Univ. of Chi. Coase-Sandor Inst. for Law \& Econ., Working Paper No. 6180, 2016), https://ssrn.com/abstract=2817151 [https://perma.cc/YTK5-T2ZV] (discussing how companies responded to changes in the JOBS Act that exempted those below a $\$ 75$ million public float from certain kinds of disclosure requirements). 
disclosures. ${ }^{29}$ Companies lobbied Congress for relief from section $404 .{ }^{30}$

A legislative response soon followed. Congress invited testimony from the Securities and Exchange Commission ("the SEC") on the costs of SOX (which addressed, among other things, the compliance costs associated with section 404(b)), ${ }^{31}$ and later asked the SEC to further study the costs of section 404 specifically. ${ }^{32}$ Congress also asked the SEC to study the cost impact of section 404(b) on companies with market capitalizations between $\$ 75$ million and $\$ 250$ million. ${ }^{33}$ As Congress requested, the SEC provided a set of recommendations for reducing the compliance burden associated with section 404(b) on that category of companies. ${ }^{34}$

Eventually, Congress responded by revising the structure of section 404 in the Dodd-Frank Wall Street Reform and Consumer Protection Act ("the Dodd-Frank Act"). ${ }^{35}$ There, Congress exempted non-accelerated filers-companies with less than $\$ 75$ million in public float ${ }^{36}$-from complying with

29 Sarbanes-Oxley Act of 2002, § 404(b). However, as Professor Coffee correctly points out, the high costs of $\S 404(\mathrm{~b})$ did not come directly from legislation, but rather from the self-regulatory initiative of the Public Company Accounting Oversight Board that required auditors to conduct a fullblown audit before they provided the required attestation. Coffee, supra note 6 , at 1027 n. 31,1038 .

30 See Coffee, supra note 6, at 1027 (describing how the business community was impacted by the costs of complying with section 404 and how, in turn, that community pressured Congress to amend the legislation).

31 Sarbanes-Oxley at Four: Protecting Investors and Strengthening Markets: Hearing Before the H. Comm. on Fin. Servs., 109th Cong. 56-64 (2006) (statement of Christopher Cox, Chairman, Securities \& Exchange Commission).

32 Dodd-Frank Act, Pub. L. No. 111-203, § 989G(b), 124 Stat. 1376, 1948 (2010).

33 Id.

34 U.S. Sec. \& Exch. Comm'n, Office of the Chief Accountant, Study and Recommendations on Section 404(B) of the Sarbanes-Oxley ACt of 2002 For Issuers With Public FloAt Between $\$ 75$ AND $\$ 250$ Million 111 13 (2011).

35 Dodd-Frank Act $\S 989 \mathrm{G}$.

36 Public float refers to the market value of the equity shares outstanding, not including those held by insiders. See Public Float, Practical Law Glossary, Item 6-382-3723 (West 2020). 
section 404(b). ${ }^{37}$ Going further, in 2012, the JOBS Act exempted "emerging growth companies" (a category created by the JOBS Act) - that is, a company with less than $\$ 1$ billion in total annual gross revenues ${ }^{38}$ _from complying with section 404(b). ${ }^{39}$

Meanwhile in the financial sector, the pendulum had swung back in the early 2000s in the run-up to the financial crisis. The pre-crisis binge on mortgage products stemmed from a decades-long decision by financial regulators to take a "light touch" approach to regulating the financial services sector. ${ }^{40}$ During those years, financial regulation was dominated by a view that the financial system should be permitted to take risk, allocate capital freely, and compete vigorously. ${ }^{41}$

37 The Dodd-Frank Act added section 404(c) to SOX. Dodd-Frank Act $\S$ 989G. For further technical explanation, see ERNST \& YoUnG, Movin' ON UP To ACCelerated Filer Status: You'll Need an Audit of ICFR For This YEAR 1-2 (2013), https://www.ey.com/en_us/assurance/accountinglink/technical-line---movin--on-up-to-accelerated-filer-status--you-l [https://perma.cc/WAE3-8C7U].

38 Jumpstart Our Business Startups Act, Pub. L. No. 112-106, § 101(a), 126 Stat. 306, 307 (2012); Jumpstart Our Business Startups Act, Frequently Asked Questions, U.S. SEc. \& Exchange Commission (Dec. 21, 2005), https://www.sec.gov/divisions/corpfin/guidance/cfjjobsactfaq-title-i-general.htm. [https://perma.cc/K7JK-VP8C].

39 Jumpstart Our Business Startups Act § 102(a).

40 See Janet L. Yellen, A View of the Economic Crisis and the Federal Reserve's Response, FED. RES. BANK S.F. (July 6, 2009), https://www.frbsf.org/economic-research/publications/economic-let-

ter/2009/july/economic-crisis-federal-reserve/ [https://perma.cc/9G78UWG6] (mentioning that regulators got "overly complacent"); Julie Stackhouse, Why Didn't Bank Regulators Prevent the Financial Crisis, FED. RES. BANK ST. LouIS (May 23, 2017), https://www.stlouisfed.org/on-the-economy/2017/may/why-didnt-bank-regulators-prevent-financial-crisis [https://perma.cc/NBA3-NVU2].

41 See Klaus Liebscher, Governor, Austrian Nat'l Bank, Speech at the Annual CSI Conference: Financial Deregulation in the EU-Chances and Challenges for Financial Stability 3 (Nov. 18, 2005), https://www.bis.org/review/r051124a.pdf [https://perma.cc/V6KQ-HZXM] (remarking that "financial stability is a condition where the financial system, comprising financial institutions, financial markets and financial infrastructures, is capable of directing capital to its most profitable risk-adjusted use without major disturbances”). 
The public rescues of certain financial institutions during that crisis $^{42}$ prompted the general public to once again focus on risk-taking in the financial sector. Congress again responded legislatively in certain provisions of the Dodd-Frank Act. Among other things, Title I of the Dodd-Frank Act increased the stringency of regulation and supervision for the largest, most complex banks. ${ }^{43}$ It increased risk-weighted and leverage capital requirements; imposed new constraints regarding liquidity; and devised a new regime of supervisory stress testing. ${ }^{44}$ Title II imposed a requirement that large, global banks prepare so-called "living wills," or resolution plans. ${ }^{45}$

Not surprisingly, the industry soon thereafter responded that the costs of Dodd-Frank and its implementing regulations were unduly onerous. According to one report, by 2016 the financial services industry was spending $\$ 10.4$ billion per year to implement Dodd-Frank related rules. ${ }^{46}$ As public choice theory would predict, once nearly a decade had passed, during which the U.S. experienced significant economic recovery, ${ }^{47}$ deregulation became politically expedient once again. ${ }^{48}$

But unlike periods of financial deregulation in the $1980 \mathrm{~s}$ and 1990s, deregulation in the 2017-19 years has been fashioned primarily by the President, not Congress.

42 See Emergency Economic Stabilization Act of 2008, Pub. L. No. 110-343, 122 Stat. 3765 (2008).

43 Dodd-Frank Act, Pub. L. No. 111-203, tit. I, 124 Stat. 1376, 1391 (2010).

44 See id. See also Beverly Hirtle \& Andreas Lehnert, Fed. Reserve BANK N.Y., Supervisory Stress Tests 12 (2014).

45 Dodd-Frank Act tit. II.

46 Ayesha Javed, Dodd-Frank Costs Reach \$36 Billion in Sixth Year, BLOOMBERG (July 22, 2016), https://www.bloomberg.com/professional/blog/dodd-frank-costs-reach-36-billion-sixth-year-2/ [https://perma.cc/RT3E-UZED].

47 See, e.g., Robin Wigglesworth \& Keith Fray, The Record-Breaking US Economic Recovery in Charts, Fin. TIMES (July 4, 2019), https://www.ft.com/content/6f8c3308-9d04-11e9-9c06-a4640c9feebb [https://perma.cc/S4HR-DCNS].

48 See supra notes 1-2 and accompanying text. 


\section{LOOSENING THE REGULATORY LEVERS}

As Part II discussed, from 1933 through 2010, Congress drove financial regulatory cycles through legislation and delegations of legislative power. In contrast, the post-2010 era has seen a shift toward presidentially driven regulation and deregulation. Presidents since the crisis have used informal methods and tools to loosen (or tighten) constraints on the financial system. This approach operates outside the well-established notice-and-comment rulemaking framework that ordinarily governs the process by which regulation is made or altered.

This Part first explains the 2017-2019 political dynamic, which has likely motivated the President's attempts at deregulating outside existing administrative law frameworks. The Part then discusses specific examples of this phenomenon.

\section{A. Legislative Inertia}

To be sure, Congress made some efforts after 2010 to statutorily dial down the Dodd-Frank Act. The first of these bills languished. ${ }^{49}$ The Financial CHOICE Act of 2017 ("the CHOICE Act"), first introduced in $2016,{ }^{50}$ was the most comprehensive bill to tone down some of the key requirements of Dodd-Frank. ${ }^{51}$ Among other things, the CHOICE Act proposed to strip the power of the Financial Stability Oversight Council ("FSOC") to designate nonbank financial companies as

49 The Senate-described by one congressman as "toxic"-has been stalled, while the conservatives supportive of the President's deregulatory priorities lack a filibuster-proof majority. Ian McKendry, Crapo: 'Toxic'Senate Will Take Time to Address Housing Finance Reform, Dodd-Frank, AM. BANKER (Feb. 15, 2017), https://www.americanbanker.com/news/crapotoxic-senate-will-take-time-to-address-housing-finance-reform-dodd-frank [https://perma.cc/P25W-6A9H].

50 Financial CHOICE Act of 2017, H.R. 10, 115th Cong. (2017).

51 See Matthew Dyckman, Financial Regulatory Reform in the Trump Administration, HaRv. L. Sch. F. ON CORP. GOvernanCE (Jan. 26, 2017), https://corpgov.law.harvard.edu/2017/01/26/financial-regulatory-reform-inthe-trump-administration [https://perma.cc/P2KV-ZWC2]. 
systemically important financial institution ("SIFIs")..$^{52}$ Among financial regulation experts, FSOC, with its SIFI designation power, is commonly regarded as a major innovation in the institutional architecture of financial stability. ${ }^{53}$ It provides a platform for regulators to appraise and address systemic risk across the financial system in a cross-sectoral manner, and forces regulators out of their pre-crisis silos.

The CHOICE Act would also have eliminated the Office of Financial Research ("the OFR"), which is a research arm of the Treasury Department. ${ }^{54}$ The OFR is a market-monitor and information-gatherer. In that role, it aides FSOC in assessing which institutions might pose systemic risks, and generally serves as an all-purpose information and data-gathering resource for various financial regulators. ${ }^{55}$ It, like FSOC, is a Dodd-Frank innovation. ${ }^{56}$ Repealing the Volcker Rule is also a component of the CHOICE Act. ${ }^{57}$ This rule, promulgated under the Dodd-Frank Act, prohibits banking entities from engaging in proprietary trading or having an interest in risk-taking entities, like hedge or private equity funds. ${ }^{58}$

But the CHOICE Act never passed. It was eclipsed by a second piece of deregulatory legislation, the Economic Growth, Regulatory Relief, and Consumer Protection Act ("the

52 H.R. $10 \S$ 151(a). See also Christina Parajon Skinner, Regulating Nonbanks: A Plan for SIFI Lite, 105 GEO. L.J. 1379, 1383 (2017).

53 See, e.g., Skinner, supra note 52, at 1389; Daniel Schwarcz \& David Zaring, Regulation by Threat: Dodd-Frank and the Nonbank Problem, 84 U.CHI. L. REV. 1813, 1817 (2017).

54 H.R. $10 \S 151(\mathrm{~b})$.

55 Dodd-Frank Act, Pub. L. No. 111-203, § 153, 124 Stat. 1376, 1415 (2010).

56 Id. $\S 152$.

57 H.R. $10 \S 901$. The Volcker Rule devolved from section 619 of the Dodd-Frank Act. See Dodd-Frank Act $§ 619$ (codified at 12 U.S.C. $§ 1851$ (2018)); Prohibitions and Restrictions on Proprietary Trading and Certain Interests in, and Relationships With, Hedge Funds and Private Equity Funds, 79 Fed. Reg. 5,536 (Jan. 31, 2014) (codified at 12 C.F.R. pts. 44, 248, 351 and 17 C.F.R. pt. 255).

58 Prohibitions and Restrictions on Proprietary Trading and Certain Interests in, and Relationships With, Hedge Funds and Private Equity Funds (Volcker Rule), 79 Fed. Reg. 5,536 (Jan. 31, 2014) (codified at 12 C.F.R. pts. 44, 248, 351 and 17 C.F.R. pt. 255). 
Economic Growth Act"). ${ }^{59}$ This legislation was much less sweeping. Its primary deregulatory accomplishment was to increase the asset threshold at which a bank is considered systemically important, from $\$ 50$ to $\$ 250$ billion. ${ }^{60}$ As a result, some smaller and mid-size banks were exempted from the Federal Reserve's mandatory stress tests and other heightened prudential standards.

While Congress during this period was judicious or inert, the President was active and effective. Ordinarily, notice-andcomment rulemaking, as prescribed by the Administrative Procedure Act ("the APA"), is the principle legal vehicle for regulating an industry. ${ }^{61}$ Agencies must also generally follow APA procedures when amending a regulation to lessen its burden on regulated parties. Accordingly, in order to substantially revise or repeal a regulation, a financial regulatory agency must usually inform the public by publishing "notice" of the change in the Federal Register, invite public commentary on the change, and respond to those comments in the final rule (regardless of whether the comments were actually heeded by the agency). ${ }^{62}$

But notice-and-comment deregulation is not particularly expedient for an executive with a strong desire to deregulate quickly, comprehensively, and with minimal external checks. The protracted public notice-and-comment process means that APA rulemakings-including deregulatory ones-will

59 Economic Growth, Regulatory Relief, and Consumer Protection Act, Pub. L. No. 115-174, 132 Stat. 1296 (2018) (to be codified in scattered sections of $12,15,20,38,42$, and 50 U.S.C.).

60 See id. $\S 401$.

61 Under the Administrative Procedure Act ("the APA"), a "rule" is an "an agency statement of general or particular applicability and future effect designed to implement, interpret, or prescribe law or policy." 5 U.S.C. $\S$ 551(4) (2018).

625 U.S.C. $§ 533$. The financial regulatory agencies' legal authority to promulgate a given rule flows from either (i) a congressional delegation of power to implement a statute, or (ii) from an agency's pre-delegated constitutive statute that pre-delegates authority to enact rules needed to fulfill its mandate. See Peter L. STRAuss ET AL., GELlHORn AND Byse's AdministraTIVE LAW: CASES AND Comments 293-94 (12th ed. 2018). 
often take a year or longer. ${ }^{63}$ And because any change must not be "arbitrary" or "capricious" 64 -meaning, it must be supported by good reasons-historically it has been assumed that Presidents had only limited berth to upend their predecessor's work. ${ }^{65}$ But presidentially driven (de)regulation has watered that precedent down, as recent Presidents have assumed an increased role in shaping regulation (and now, deregulation) through channels outside of legislation or formal rulemaking.

To be fair, some deregulation during the Trump presidency happened through notice-and-comment rulemaking. The Federal Reserve Board lightened certain stress testing requirements for banks of all sizes, including those systemically important banks with over $\$ 250$ billion in assets. ${ }^{66}$ Specifically, the Federal Reserve issued final rules to reduce the frequency with which some banks are required to undergo stress testing and eliminated the requirement that banks publicly disclose the results of their own company-run capital stress tests. ${ }^{67}$ But, as will be discussed below, much of the financial deregulation of the 2017-19 period happened in informal, sub-legal spaces.

63 John B. Bellinger, III et Al., Arnold \& Porter, Presidential PowERs: Avenues Available to President Trump to Change LaW and Policy 2 (2016), http://www.apks.com/en/perspectives/publications/2016/12/presidential-powers-avenues-available [https://perma.cc/5UXQ-TS75].

645 U.S.C. $\S 706(2)(\mathrm{A})$.

65 See BELlinger, III ET AL., supra note 63.

66 See Letter from Randal Quarles, Vice Chairman for Supervision, Fed. Reserve Sys., to Bd. of Governors of the Fed. Reserve Sys. 3, 11 (Oct. 24, 2018), https://www.federalreserve.gov/aboutthefed/boardmeetings/files/board-memo-20181031.pdf [https://perma.cc/T8KR-T2EG] (applying requirements on banks with at least $\$ 100$ billion but less than $\$ 250$ billion in total assets); Prudential Standards for Large Bank Holding Companies, Savings and Loan Holding Companies, and Foreign Banking Organizations, 84 Fed. Reg. 59,032 (Nov. 1, 2019) (codified at 12 C.F.R. pts. 217, 225, 238, 242, and 252).

67 See Letter from Randal Quarles to Bd. of Governors, supra note 66, at 3; Regulations LL and YY; Amendments to the Company-Run and Supervisory Stress Test Rules, 84 Fed. Reg. 4,002, 4,003, 4,009-10 (Feb. 14, 2019) (to be codified at 12 C.F.R. pts. 238 and 252). 


\section{B. Presidential (De)regulation in Action}

Presidentially driven deregulation refers to the executive's use of informal, sub-legal tools to effectuate the spirit of deregulation, even if not its lawful letter. As the following examples will show, presidentially driven (de)regulation sidesteps the legislature directly. It also avoids the legislature indirectly by sidestepping the delegation of power that Congress confers to the financial regulatory agencies to make (or unmake) formal rules.

The following Section provides some descriptive analysis of past (Obama Administration) and present (Trump Administration) uses of presidentially driven (de)regulation. Again, as earlier noted, this Article is agnostic on the merits of regulation or deregulation. Rather, this Section makes a procedural point: increasingly, the executive drives (de)regulation, and with it, swings the pendulum (i.e., cycles) of financial regulation.

\section{Agency Guidance}

Agencies often issue guidance to flesh out the nuances of a regulation, or to clarify ambiguities. ${ }^{68}$ However, because agencies are not required to engage in notice-and-comment procedures in connection with interpretative guidance, ${ }^{69}$ regulators can in effect dial-up or dial-down the stringency of a regulation through non-binding guidance. ${ }^{70}$ And courts generally

68 See STRAUSS ET AL., supra note 62 , at 377.

69 While agencies sometimes might issue a public notice of a new interpretative guidance, they are not legally obligated to do so under the APA. See Perez v. Mortg. Bankers Ass'n, 575 U.S. 92, 101 (2015).

70 In 2015, the Supreme Court held that the APA does not require federal regulatory agencies to engage in notice and comment before it can issue interpretative guidance that "deviates significantly from one the agency has previously adopted." Id. at 95. As regulatory expert attorneys at Arnold \& Porter Kaye Scholer LLP have noted, even though "these interpretations do not carry the force of law, they can be used to limit the scope or effect of a rule, because agency interpretations command 'Auer deference." BELLINGER III, ET AL., supra note 63, at 3. 
defer to agency guidance, provided it is not arbitrary or capricious. $^{71}$

Regulating via guidance was popularized by the Obamaera financial regulatory agencies, and extended in the Trump Administration. ${ }^{72}$ In the financial regulation space, perhaps the most famous piece of regulatory guidance which substantively impacted the financial services industry dealt with leveraged lending. ${ }^{73}$ That guidance, in broad strokes, capped bank lending at six times debt-to-EBITDA, absent regulatory review. ${ }^{74}$ Commentators remarked that using guidance to regulate was an abuse of executive power. ${ }^{75}$

Notably, just as guidance can be used to regulate informally, so, too, can it be deployed to deregulate informally. The current administration, for example, has softened its attitude toward enforcement of the leveraged lending guidance, likely

71 See BELlinger III, ET AL., supra note 63, at 3.

72 Undoubtedly, agency guidance is issued outside of the financial regulatory arena. This Article does not suggest agency guidance is unique to financial regulation, only that its impact may be.

73 See Interagency Guidance on Leveraged Lending, 78 Fed. Reg. 17,766 (Mar. 22, 2013); see also Steven Davidoff Solomon, Obstacles in Regulators' Push to Reduce Leveraged Lending, N.Y. Times (July 7, 2015), https://www.nytimes.com/2015/07/08/business/dealbook/balancing-act-forregulators-seeking-to-curb-leveraged-loans.html [https://perma.cc/R2BKE6ST] (referring to the guidance as "the classic sort of wishy-washy standards that do not set bright lines but are so broad in wording they give regulators wide latitude to step in when they decide a leveraged loan is too risky" and noting that "[e]ven the definition of a leveraged loan is uncertain under the guidelines").

74 See Interagency Guidance on Leveraged Lending, 78 Fed. Reg. at 17,773 .

75 See John-Michael Seibler, Court Ruling Rebukes Obama-Era Practice That Flouted Rule of Law, Heritage Found. (Feb. 27, 2018), https://www.heritage.org/courts/commentary/court-ruling-rebukes-obamaera-practice-flouted-rule-law [https://perma.cc/24PF-9TZ3] (discussing the "abuse of guidance documents"). But see Dana A. Elfin, DOJ Says Guidance Documents Can't Drive Enforcement Actions, Bloomberg (Jan. 26, 2018), https://news.bloomberglaw.com/us-law-week/doj-says-guidance-documentscant-drive-enforcement-actions [https://perma.cc/T42H-U9ST] (describing a Justice Department policy that stated that guidance can no longer form the basis of enforcement actions). 
contributing to the uptick observed in leveraged lending by banks. ${ }^{76}$

\section{Enforcement Priorities}

Secondly, acting at the behest of a President, a financial regulatory agency can level down (or level up) the intensity of a regulation by changing its enforcement priorities. For an agency like the SEC or Commodity Futures Trading Commission that regulates through enforcement, stepping back on enforcement can have a pronounced deregulatory effect.

Now, because financial regulatory agencies are formally independent of the President, an executive can guide enforcement priorities only insofar as the agencies are willing to follow. But despite their independent status, financial regulatory agencies have at certain points in history bent to executive prerogative or pressure. The Federal Reserve, for instance, has sometimes followed executive instructions even when not binding, as has the SEC. ${ }^{77}$ Indeed, signs of enforcement at the SEC eased just several months into the new administration. ${ }^{78}$ Relatedly, agencies can drop from their

76 See Andrew Berlin, Regulated Banks Soften Stance on Leveraged Lending Guidance, REUTERS (Apr. 19, 2018), https://www.reuters.com/article/us-lev-regulation/regulated-banks-soften-stance-on-leveraged-lendingguidance-idUSKBN1HQ2XV [https://perma.cc/UVH4-QRKQ]; Will CaigerSmith \& Alex Plough, Banks Pile Into Riskier Deals As Influence of Obamaera Lending Guidelines Melts Away, Forbes (Apr. 26, 2018), https://www.forbes.com/sites/debtwire/2018/04/26/banks-pile-into-riskierdeals-as-influence-of-obama-era-lending-guidelines-meltsaway/\#63deb1bf5be1 [https://perma.cc/789M-CTDL].

77 See Michael Salib \& Christina Parajon Skinner, Executive Override of Central Banks: A Comparison of the Legal Frameworks in the United States and the United Kingdom, 108 GEO. L.J. 905 (2020); BRIAN V. BREHENY et al., Skadden, Trump's Focus on Deregulation Could Shape SEC PriORITIES IN 2017 (2017), https://www.skadden.com/insights/publications/2017/01/trumps-focus-on-deregulation-could-shape-sec-prior [https://perma.cc/F6R5-9EZ].

78 See Peter J. Henning, Signs of a Step Back in Financial Regulatory Enforcement, N.Y. Times (Feb. 20, 2017), https://www.nytimes.com/2017/02/20/business/dealbook/signs-of-a-step-back-in-financialregulatory-enforcement.html?ref=dealbook\&_r=0 [https://perma.cc/V7DTCY3R]. See also Benjamin Bain, Interim SEC Boss Goes Beyond Caretaker 
agendas previously begun initiatives to regulate-or ignore regulatory mandates completely. ${ }^{79}$ For one example, the SEC announced in 2017 that it would cease its longstanding effort to further regulate bankers' compensation. ${ }^{80}$

A few more examples further illustrate the practice. In line with the Trump Administration's priorities, the Consumer Financial Protection Bureau ("the CFPB") has dramatically reduced the intensity of its enforcement actions. Between November 2017 and April 2018, the CFPB filed only one enforcement action under its interim director, former Senator, Mick Mulvaney. ${ }^{81}$ For context, the CFPB had been accused of

Role To Revisit Rules, BloOMBERG (Feb. 3, 2017), https://www.bloomberg.com/news/articles/2017-02-03/interim-sec-boss-goes-beyond-care-

taker-role-to-plot-rules-revamp [https://perma.cc/V7NN-BC5S] (noting the SEC's reconsideration of the pay ratio rule); Dave Michaels, SEC To Reconsider Enforcing 'Conflict Minerals' Rule, Acting Chief Says, WaLl ST. J. (Jan. 31, 2017), https://www.wsj.com/articles/sec-to-reconsider-enforcing-conflictminerals-rule-acting-chief-says-1485913422 [https://perma.cc/QNP7MPKM] (noting the SEC's reconsideration of the conflict minerals rule). Moreover, in addition to an established (albeit informal) tradition of voluntary compliance with executive priorities, the President now has the Financial Stability Oversight Council ("FSOC") through which to exercise political control. Recall that FSOC includes as its members the heads of most of the independent financial regulatory agencies, but is led by the Treasury Secretary, who heads an executive branch agency and is thus answerable directly to the President's will. See 12 U.S.C. § 5321(b) (2018).

79 See Stephen Bainbridge, Can the SEC Unilaterally Ignore DoddFrank Rule Making Requirements?, PROFEssorBaInBRIDGE.COM (July 24, 2017), http://www.professorbainbridge.com/professorbainbridgecom/2017/07/can-the-sec-unilaterally-ignore-dodd-frank-rule-making-requirements.html [https://perma.cc/WR8M-47XV] (offering commentary on whether it is lawful for the SEC to ignore Dodd-Frank rulemaking requirements).

80 See Telis Demos \& Dave Michaels, Trump's Move on Wall Street Pay Too Late for Bankers, WALL ST. J. (July 23, 2017), https://www.wsj.com/articles/wall-street-outlasts-congress-on-banker-pay-but-still-loses1500847919 [https://perma.cc/EQH6-5DZ7]. For a scholarly account of this policy problem and debate, see Lucian A. Bebchuk \& Holger Spamann, Regulating Bankers' Pay, 98 GEO. L.J. 247, 265-66 (2010).

81 See Greg Ip, Financial Deregulation Throws Fuel on an Already-Hot Economy, WALL ST. J. (Apr. 25, 2018), https://www.wsj.com/articles/financial-deregulation-throws-fuel-on-already-hot-economy-1524654001 [https://perma.cc/53QP-VHLZ]. 
"overreach" in years prior. ${ }^{82}$ Meanwhile, to make public monitoring of these enforcement actions more difficult, the agency eliminated public access to its database of complaints lodged against financial institutions. ${ }^{83}$ Additionally, the CFPB then later expanded its policy of issuing no-action letters to firms experimenting with innovation. ${ }^{84}$ To be clear, there can be economic value in providing a wide regulatory berth for innovation; the point here is merely that the increase of no-action letters could be inversely related to enforcement of consumer protection violations.

There are other hypothetical ways that financial regulators could scale back enforcement without legislation or notice-and-comment rulemaking in order to lighten the burden of regulation. Consider stress testing. The Federal Reserve conducts annual or biennial supervisory stress tests of the banks under its supervision. ${ }^{85}$ The test involves the Federal Reserve's creation of baseline and severely adverse economic scenarios, to which banks have to respond with a plan for remaining solvent-that is, banks must demonstrate that their equity capital is adequate to withstand the stressful events. ${ }^{86}$

82 See Dennis Shaul, What Went Wrong With the CFPB, WALL ST. J. (Nov. 19, 2017), https://www.wsj.com/articles/what-went-wrong-with-thecfpb-1511072512 [https://perma.cc/BK9Y-VYD9]; Kate Berry, CFPB's First Jury Trial to Test Agency Overreach, AM. BANKer (Feb. 22, 2017), https://www.americanbanker.com/news/cfpbs-first-jury-trial-to-testagency-overreach [https://perma.cc/PF6G-3GQ6]; Blaine Luetkemeyer, The CFPB Is Hurting Consumers And It Needs To Be Reformed, ForBEs (Mar. 31, 2017), https://www.forbes.com/sites/realspin/2017/03/31/the-cfpb-ishurting-consumers-and-it-needs-to-be-reformed/\#7e00a1e619ed [https://perma.cc/6KHB-SMLU].

83 See Press Release, Consumer Fin. Prot. Bureau, CFPB Announces First No-Action Letter to Upstart Network (Sept. 14, 2017), https://www.consumerfinance.gov/about-us/newsroom/cfpb-announcesfirst-no-action-letter-upstart-network/ [https://perma.cc/6PTL-22XZ].

84 See id.

85 Although the Fed is technically independent of the political branches, there is ample literature debating the consistency of that independence across time and issue. See, e.g., Salib \& Skinner, supra note 77, at 911.

86 See Bd. of Governors of the Fed. Reserve Sys., Comprehensive CAPital Analysis And Review 2017: Assessment Framework AND REsults 1-3 (2017); see also Press Release, Bd. of Governors of the Fed. Reserve Sys., 
The Fed has used notice-and-comment rulemaking procedures to adjust the parameters of its stress tests. For example, it has made the test more predictable. ${ }^{87}$ Banks had long asked for the stress scenarios to be published ahead of time, emphasizing the difficulty of responding to hypothetical scenarios. In 2018, the Federal Reserve responded with a proposal to release the models that it uses to estimate hypothetical losses at banks. ${ }^{88}$ Those changes took effect in $2019 .{ }^{89}$ But the Fed could make stress testing more relaxed in other, simpler ways that would not require notice-and-comment rulemaking. For instance, the Federal Reserve could relax the assumptions in its scenarios, thereby making its hypotheticals less intense. That could be a pressure point that future Presidents exploit. 90

Federal Reserve Board Releases Hypothetical Scenarios for its 2020 Stress Test Exercises (Feb. 6, 2020), https://www.federalreserve.gov/newsevents/pressreleases/bcreg20200206a.htm [https://perma.cc/J8KU-QGPX].

87 See Enhanced Disclosure of the Models Used in the Federal Reserve's Supervisory Stress Test, 84 Fed. Reg. 6,784 (Feb. 28, 2019).

88 Press Release, Bd. of Governors of the Fed. Reserve Sys., Federal Reserve Board Requests Comment on Package of Proposals that Would Increase the Transparency of its Stress Testing Program (Dec. 7, 2017), https://www.federalreserve.gov/newsevents/pressreleases/bcreg20171207a.htm [https://perma.cc/9MCE-MNMA].

89 See Enhanced Disclosure of the Models Used in the Federal Reserve's Supervisory Stress Test, 84 Fed. Reg. at 6,784.

90 Experts and commentators have also voiced concern over President Trump's recent nominations to the Board of Governors, given the nominees' conspicuous political views and the fear that when monetary policy bends to politics, high levels of inflation may follow. See, e.g., Gina Heeb, Trump's Latest Fed Picks Have Experts Worried About Central Bank Independence, Bus. INSIDER (Apr. 9, 2019), https://markets.businessinsider.com/news/stocks/why-is-the-federal-reserve-independent-20194-1028097729 [https://perma.cc/3QFQ-EL7L]; Balazs Koranyl, ECB's Draghi Worried About Fed's Independence, REUTERs (Apr. 13, 2019), https://www.reuters.com/article/us-imf-worldbank-ecb/ecbs-draghi-worried-about-feds-independence-idUSKCN1RP0K9 [https://perma.cc/E6X5M3ZC]. 


\section{Agency Priorities}

Executives are also able to adjust the intensity of the overall financial regulatory framework through FSOC, which was created by the Dodd-Frank Act. ${ }^{91}$ FSOC was designed to function like a "financial stability czar." ${ }^{2}$ Unlike a traditional regulatory agency, FSOC is a true council; it is comprised of fourteen members of the various financial regulatory agencies. ${ }^{93}$ Importantly, FSOC is spearheaded by the Treasury Secretary ${ }^{94}$ - who serves at the pleasure of the President. Inherently, this structure subjects FSOC to political pressure..$^{95}$

FSOC has significant influence over the tone and rigor of financial regulation, at least where financial stability issues are concerned. It has a broad mandate to monitor the financial system for present and emerging financial stability risks. ${ }^{96}$ This includes designating nonbank financial companies, which would otherwise be outside of the Federal Reserve's jurisdiction, as "systemically important," thereby subjecting them to heightened Fed regulation and supervision. ${ }^{97}$ FSOC can also make nonbinding recommendations to financial regulators regarding the need to regulate additional financial activities, if it determines these activities pose a risk to financial

91 Dodd-Frank Act, Pub. L. No. 111-203, §§ 111-112, 124 Stat. 139298 (2010) (codified as amended at 12 U.S.C. $\S \S 5321-5322$ (2018)) (establishing FSOC in $\S 111$ and enumerating its purposes and duties in $\S 112$ ).

92 Skinner, supra note 52 , at 1382.

93 See 12 U.S.C. $\$ 5321(b)$ (2018).

94 Id.

95 See Donald Kohn, External Member, Fin. Policy Comm., Bank of Eng., Speech at the Global Financial Forum: Comparing UK and US Macroprudential Systems 4 (May 11, 2014), https://www.bankofengland.co.uk//media/boe/files/speech/2014/comparing-uk-and-us-macroprudential-systems-lessons-for-china [https://perma.cc/2XKZ-YF98] (remarking on the political nature of FSOC).

96 Dodd-Frank Act $\S 112(\mathrm{a})(1)(\mathrm{A}), 12$ U.S.C. $\S 5322(\mathrm{a})(1)(\mathrm{A}) ;$ see also Authority to Require Supervision and Regulation of Certain Nonbank Financial Companies, 77 Fed. Reg. 21,637, 21,637 (Apr. 11, 2012) (to be codified at 12 C.F.R. pt. 1310).

97 Dodd-Frank Act $§ 113,12$ U.S.C. $§ 5323$. 
stability. ${ }^{98}$ While these recommendations are nonbinding, agencies have complied with some of them. ${ }^{99}$

FSOC was unpopular from the start, from both political and private industry corners. In its early days, some factions of Congress complained about FSOC's lack of transparency and its unprecedented power. ${ }^{100}$ Meanwhile, the industry resisted FSOC's designation power on the ground that its analysis was subjectively applied and insensitive to the business model of the companies that it had labeled. ${ }^{101}$ That political antipathy intensified with the Trump Administration. In his early days in office, the President issued a memorandum ${ }^{102}$ requiring the Treasury Secretary to review FSOC's designation process for propriety and efficacy, and to generally determine whether FSOC's other powers were consistent with the President's order that the financial system be regulated "in a manner" that, among other things, is "efficient, effective, and appropriately tailored." 103

Since that time, FSOC's priorities have markedly shifted. During the prior administration, FSOC had been active in

98 Dodd-Frank Act $§ 120,12$ U.S.C. $§ 5330$.

99 See, e.g., Examining Insurance Capital Rules and FSOC Process: Hearing Before the Subcomm. on Sec., Ins., and Inv. of the S. Comm. on Banking, Hous., \& Urban Affairs, 114th Cong. 24 (2015) (statement of Robert Falzon, Executive Vice President and Chief Financial Officer, Prudential Financial) ("A recommendation made by FSOC is not binding on such agencies, but the Dodd-Frank Act includes a 'name and shame' provision that encourages the adoption of a recommendation. That provision requires an agency to notify FSOC within 90 days if it does not intend to follow the recommendation, and FSOC is required to report to Congress on the status of each recommendation.”). See also Council of Inspectors Gen. On Fin. Oversight, CIGFO 2017-001, Audit of the Financial Stability Oversight Council's EFForts to Promote Market Discipline 11 (2017) (describing how the SEC reformed its rules governing money market mutual funds in 2014 pursuant to FSOC's recommendation).

100 See Skinner, supra note 52, at 1381-82.

101 See id. at 1396-1400.

102 Presidential Memorandum on the Financial Stability Oversight Council, 2017 DAILY ComP. PREs. Doc. 265 (Apr. 21, 2017), https://www.govinfo.gov/content/pkg/DCPD-201700265/pdf/DCPD-

201700265.pdf [https://perma.cc/EAY8-DWPF].

103 See Exec. Order No. 13772, 82 Fed. Reg. 9,965 (Feb. 3, 2017). 
designating non-bank financial companies as systemically important-MetLife, AIG, GE Capital, and Prudential had all received the designation, and FSOC had been considering whether further designations in the asset management industry were warranted. ${ }^{104}$ By this point, all of those designations have been rescinded. In 2015, MetLife sued FSOC in federal court, arguing that the designation was arbitrary and capricious. ${ }^{105}$ It prevailed on that suit in $2016 .{ }^{106}$ The government had intended to appeal, but dropped the case with the arrival of the new administration. ${ }^{107}$ FSOC subsequently voted to rescind the designations of AIG in September 2017, and Prudential, in October 2018. ${ }^{108}$ As Professor Jeremy Kress has argued, given the minimal effort these firms made to restructure their business to reduce their systemic footprint, it is hard to think of anything other than a political explanation for these de-designations. ${ }^{109}$

The designation powers of FSOC seem likely to lay dormant unless and until a change of administration. Even further, FSOC has effectively abandoned the designation

104 See Nonbank Financial Company Designations, U.S. DeP’T TreasURY, https://www.treasury.gov/initiatives/fsoc/designations/Pages/default.aspx [https://perma.cc/BJ8R-9DQ2] (last visited Mar. 19, 2020).

105 Complaint at 2-7, MetLife, Inc. v. Fin. Stability Oversight Council, 177 F. Supp. 3d 219 (D.D.C. 2016) (No. 15-45), 2015 WL 4064567.

106 MetLife, Inc. v. Fin. Stability Oversight Council, 177 F. Supp. 3d 219, 242 (D.D.C. 2016).

107 See Lalita Clozel, Court Drops Government's Appeal of MetLife Case, WALL ST. J. (Jan. 23, 2018), https://www.wsj.com/articles/court-dropsgovernments-appeal-of-metlife-case-1516742046 [https://perma.cc/NX87UV5U].

108 Fin. Stability Oversight Council, Notice and Explanation of THE BASIS FOR THE FINANCIAL STABILITY OvERSIGHT COUNCIL's RESCISSION OF its Determination Regarding American International Group, Inc. (2017); Fin. Stability Oversight Council, Notice and Explanation of the BASIS FOR THE FinANCIAL STABILITY OvERSIGHT COUNCIL's RESCISSION OF ITS Determination Regarding Prudential Financial, InC. (2018). GE's designation was rescinded in June 2016 after a massive downsizing of its capital markets arm, GE Capital. See Fin. STABILITy Oversight Council, BAsis For the Financial Stability Oversight Council's Rescission of Its DetermiNATION REGARDing GE CAPITAL GLOBAL Holdings, LLC (2016).

109 See Jeremy C. Kress, The Last SIFI: The Unwise and Illegal Deregulation of Prudential Financial, 71 Stan. L. REV. OnLIne 171 (2018). 
process altogether, in favor of an activities-based approach. Notably, this shift was effectuated through interpretative guidance. ${ }^{110}$ Several scholars have suggested that an activities-based approach, without an accompanying entity-based approach, is too weak and-in effect-deregulatory in nature. ${ }^{111}$

The Trump Administration also pressed for the adoption of a requirement that FSOC engage in cost-benefit analyses before designating a nonbank SIFI. ${ }^{112}$ Requiring a cost-benefit analysis was, in turn, also adopted in the 2019 proposed interpretive guidance. ${ }^{113}$ While there is merit to cost-benefit analysis generally, requiring it would depart from the current status quo insofar as financial regulators are generally not required to engage in the procedure to validate their rulemakings. ${ }^{114}$ Because there are inherent challenges in establishing the costs and benefits of financial stability, some have suggested the requirement would stifle further FSOC designation. ${ }^{115}$

In sum, given the governance and structure of FSOC, it has become a key vehicle for presidentially driven deregulation, at least where the corpus of financial stability regulation is concerned.

110 Authority To Require Supervision and Regulation of Certain Nonbank Financial Companies, 84 Fed. Reg. 71,740 (Dec. 30, 2019) (to be codified at 12 C.F.R pt. 1310); see supra Section III.B.1.

111 See Jeremy C. Kress et al., Regulating Entities and Activities: Complementary Approaches to Nonbank Systemic Risk, 92 S. CAL. L. REV. 145556 (2019).

112 U.S. DEP'T OF THE TREASURY, FinANCIAL STABILITy OvERSight COUNCil Designations 27 (2017).

113 Authority To Require Supervision and Regulation of Certain Nonbank Financial Companies, 84 Fed. Reg. at 71,753.

114 See id.

115 See John C. Coates IV, Cost-Benefit Analysis of Financial Regulation: Case Studies and Implications, 124 YALE L.J. 882 (2015); Jeffrey N. Gordon, The Empty Call for Benefit-Cost Analysis in Financial Regulation, 43 J. Legal Stud. S351 (2014); see also Eric A. Posner \& E. Glen Weyl, CostBenefit Analysis of Financial Regulations: A Response to Criticisms, 120 Yale L.J. F. 246 (2015); Eric A. Posner \& E. Glen Weyl, Benefit-Cost Paradigms in Financial Regulation, 43 J. LEGAL STUD. S1 (2014). 


\section{Staffing Decisions}

Trimming down staffing is another subtle way of accomplishing the impact of a more formal deregulatory rule. Staff cuts among the financial regulatory agencies have been pronounced in the past two and a half years. Perhaps most notably, the staff at the Office of Financial Research ("the OFR") has been dramatically reduced. ${ }^{116}$ As earlier discussed, the OFR was created by the Dodd-Frank Act as an informationgathering and analysis body adjunct to FSOC. 117 The idea behind the OFR was to create an agency that could "anticipate . .. economic storms ... and issue warnings to help authorities contain the damage." 118 But the OFR was also viewed by the Trump Administration as a product of overreach, and its budget has subsequently been trimmed by around onefourth. ${ }^{119}$ The first leader of the OFR, Dick Berner, stepped down in 2017, a move widely regarded as a significant setback to the Office. ${ }^{120}$

Again, these kinds of staffing changes can significantly change the ethos - and the capacity - of a regulatory agency. As one pundit remarked, "[w] hat may matter most . . is not how the Trump administration changes the rules, but the people it appoints to enforce them."121

116 See Ryan Tracy, Washington’s $\$ 500$ Million Financial-Storm Forecaster is Foundering, WALL ST. J. (Feb. 19, 2018), https://www.wsj.com/articles/washingtons-500-million-financial-storm-forecaster-is-foundering1519067903 [https://perma.cc/7HBW-S8JX].

117 Dodd-Frank Act, Pub. L. No. 111-203, § 152, 124 Stat. 1376, 1413 (2010).

118 Tracy, supra note 116. See also Editorial Bd., So Much for that Financial Early-Warning System, BloOMBERG (Mar. 13, 2018), https://www.bloomberg.com/opinion/articles/2018-03-13/trump-shouldn-tundermine-the-office-of-financial-research [https://perma.cc/84W8-Y6NH].

119 Tracy, supra note 116.

120 Editorial Bd., supra note 118.

121 Opinion, Donald Trump's Uphill Battle Against Federal Regulations, Fin. TIMES (Jan. 31, 2018), https://www.ft.com/content/67cf9b3405d7-11e8-9650-9c0ad2d7c5b5 [https://perma.cc/8MQU-95CP]. 


\section{Rule Delay}

The President can also strangle regulation by pressing for indefinite delay. ${ }^{122}$ The Trump Administration's decision to delay the Department of Labor's fiduciary duty rule is a prime example. The fiduciary duty rule was issued by President Obama's Department of Labor, which would have imposed a broad duty on all financial advisers who work with retirement assets or provide retirement planning advice to act in their client's "best interests." 123 For context, this duty sweeps broader than the one that previously governed registered investment advisors, which mandated only that advisors provide investment advice that is "suitable" for their clients. ${ }^{124}$ The financial advisory industry argued that the rule would be complicated to interpret and follow, thereby raising compliance and legal costs in the industry and, as a consequence, ultimately increasing the cost of retirement advice. ${ }^{125}$

122 Connor Raso, Trump's Deregulatory Efforts Keep Losing in Courtand the Losses Could Make It Harder for Future Administrations to Deregulate, BRookings (Oct. 25, 2018), https:/www.brookings.edu/research/trumps-deregulatory-efforts-keep-losing-in-court-and-the-lossescould-make-it-harder-for-future-administrations-to-deregulate/ [https://perma.cc/89JY-AV4W] ("In an extreme case, an indefinite delay may effectively kill a rule.").

123 See Christina Skinner \& Genevieve Helleringer, Conflicts of Interest: Comparing Compliance and Culture in the United States and United Kingdom, in Governance of Financial Institutions 489 (Danny Busch et al. eds., 2019).

124 See General Information on the Regulation of Investment Advisors, U.S. SEC. \& ExCHANGE Commission (Mar. 11, 2011), https://www.sec.gov/divisions/investment/iaregulation/memoia.htm [https://perma.cc/NPS2246E]; Suitability of Investment Advice Provided by Investment Advisers; Custodial Account Statements for Certain Advisory Clients, Investment Advisers Act Release No. 1406, 59 Fed. Reg. 13,464 (proposed Mar. 16, 1994); see also Commission Interpretation Regarding Standard of Conduct for Investment Advisers, 84 Fed. Reg. 333,669, 33,672 nn.33-34 (July 12, 2019) (to be codified at 17 C.F.R. pt. 276).

125 See, e.g., U.S. Chamber of Commerce, The Data Is In: The FiducIARy Rule Will HaRm Small Retirement SAVers (2017), https://www.uschamber.com/sites/default/files/ccmc_fiduciaryrule_harms_smallbusiness.pdf [https://perma.cc/M97Y-FG2Z]. 
On February 3, 2017, President Trump issued a memo directing the Secretary of Labor to review the economic and legal basis for the rule. ${ }^{126}$ In August 2017, the Department of Labor requested that the Office of Management and Budget delay implementation of certain aspects of the rule by eighteen months, and that delay was finalized in November 2017. ${ }^{127}$ Since that time, the Fifth Circuit Court of Appeals has ruled that the Department of Labor exceeded its authority in issuing the rule. ${ }^{128}$ Together with the delay, most believe that the fiduciary duty rule is now, effectively, dead. ${ }^{129}$

\section{Information Signaling}

Even softer still, the Trump Administration has made ample use of communications to signal a light touch approach to financial regulation. Without changing any rules or stated guidance, this method has indicated that the industry will have latitude to experiment and take risks with perhaps less scrutiny than before.

The most significant examples of this kind of signaling were the series of Treasury white papers issued over the period of 2017-2018 on various components of the financial services sector. ${ }^{130}$ Each of these reports covered a different

${ }^{126}$ Presidential Memorandum on Fiduciary Duty Rule, 2017 DAILY Comp. Pres. Doc. 95 (Feb. 3, 2017), https://www.govinfo.gov/content/pkg/DCPD-201700095/pdf/DCPD-201700095.pdf

[https://perma.cc/R4XB-FENK].

127 See Conflict of Interest Final Rule, U.S. DEP'T LAB., https://www.dol.gov/agencies/ebsa/laws-and-regulations/rules-and-regulations/completed-rulemaking/1210-AB32-2 [https://perma.cc/U8WP-WG62] (last visited Mar. 19, 2020).

128 Chamber of Commerce of the U.S. v. U.S. Dep't of Labor, 885 F.3d 360, 381 (5th Cir. 2018).

129 Just before this Article was sent to print, the Department of Labor proposed a new version of this rule. See Improving Investment Advice for Workers \& Retirees, 85 Fed. Reg. 40,834 (proposed July 7, 2020) (to be codified at 29 C.F.R. pt. 2550).

130 The reports were essentially commissioned by Executive Order 13772 , which called on the Treasury to identify laws and regulations which were inconsistent with the order's "core principles of financial regulation." Exec. Order No. 13772, 82 Fed. Reg. 9,965 (Feb. 3, 2017). 
ground, but shared the same theme: government can better support the efficiency of markets, and there is room and reason for regulation to be winnowed down.

The first report addressed banks and credit unions. ${ }^{131}$ The report generally recommended that bank regulation be made leaner, and that some of Dodd-Frank requirements (such as heightened capital) as applied to certain areas of the banking sector be examined. ${ }^{132}$ The second report addressed capital markets. ${ }^{133}$ Recommendations from that report included reducing burdens on companies interested in going public, streamlining and/or tailoring disclosure obligations, and adding rigor to the rulemaking process by, for example, including more economic analysis. ${ }^{134}$ The third report offered a view on the asset management industry. Notably, recommendations here included shifting to an activities-based approach when evaluating systemic risk in the industry, delaying the implementation of the fiduciary duty rule, and increasing the transparency of the international standard-setting process. ${ }^{135}$

The final report addressed nonbank financials, fintech, and innovation. ${ }^{136}$ The general theme of that report was that regulation should be designed to enable the development of key competitive technologies. ${ }^{137}$ The report made clear that "Treasury supports encouraging the launch of new business models as well as enabling traditional financial institutions, such as banks, asset managers, and insurance companies, to

131 U.S. Dep't of Treasury, A Financial System that Creates EcoNOMIC OPPORTUNITIES: BANKS AND CREDIT UNIONS (2017).

132 Id

133 U.S. DeP't of Treasury, A Financial System that Creates EcoNOMiC OPPORTUNITIES: CAPITAL MARKETS (2017).

134 Id. Ironically, a further recommendation was to limit the imposition of new regulations made through informal guidance, no action letters, or interpretations. Id. at 183. As the saying goes, what's good for the goose is good for the gander.

135 See U.S. DeP'T of Treasury, A Financial System that Creates ECONOMic Opportunities: Asset MANAGEMENT AND INsurAnCE (2017).

136 U.S. DeP'T of Treasury, A Financial System that Creates EcoNOMic Opportunities: Nonbank Financials, Fintech and InNovation (2018).

137 Id. 
pursue innovative technologies to lower costs, improve customer outcomes, and improve access to credit and other services."138

\section{Public Pressure}

As a final example of this new breed of presidential persuasion over financial regulation, President Trump has pressured Federal Reserve decision makers through public criticism. In particular, the President has taken aim at the Federal Open Market Committee's ("FOMC's") decision to raise interest rates-using harsh criticism of Chairman Powell as a means of pressuring the Fed Board to change course. 139

In November 2018, President Trump told the press that he wanted to "fire" the sitting Chairman of the Federal Reserve Board of Governors, Jerome Powell. ${ }^{140}$ As the President told reporters, "I'm not even a little bit happy with my selection of Jay. Not even a little bit. And I'm not blaming anybody, but I'm just telling you I think that the Fed is way off-base with what they're doing." 141 In another comment to the press, Trump remarked, "[t]he only problem our economy has is the Fed. They don't have a feel for the market. The Fed is like a

138 Id. at 9 .

139 This method follows a long line of executive branch incursions into central bank independence. For a fuller treatment of this subject, which also compares the executive branch's legal and sub-legal powers to direct central banks in the U.S. and U.K., see Salib \& Skinner, supra note 77.

140 See Philip Rucker et al., Trump Slams Fed Chair, Questions Climate Change and Threatens to Cancel Putin Meeting in Wide-ranging Interview with Post, WAsH. Post (Nov. 27, 2018), https://www.washingtonpost.com/politics/trump-slams-fed-chair-questions-climate-change-andthreatens-to-cancel-putin-meeting-in-wide-ranging-interview-with-thepost/2018/11/27/4362fae8-f26c-11e8-aeea-b85fd44449f5_story.html [https://perma.cc/U5DF-U89M].

141 Id. See also Billy House \& Erik Wassan, Powell Told Democrats Fed Won't Bend to Pressure, Sources Say, Bloomberg (Apr. 11, 2019), https:/www.bloomberg.com/news/articles/2019-04-11/democrats-raise-concerns-on-fed-independence-before-powell-talk [https://perma.cc/DT46HGJN]. 
powerful golfer who can't score because he has no touch. He can't putt." 142

In January 2019, the Fed announced that it would not be pursuing any further rate increases. ${ }^{143}$ Just one month prior, Powell had said that the rest of the Board thought that they would raise rates at least two more times in $2019 .{ }^{144}$ Of course, FOMC members are entitled and expected to change their opinions on monetary policy based on prevailing economic conditions. But to the extent that changes in monetary policy reflect some reaction to presidential pressure, it would be troubling for the central bank's independence-which is required to guard against price instability. Indeed, one of the most dominant rationales for a central bank's independence is to safeguard its ability to make nonpolitical decisions about monetary policy.

Presidents often desire accommodative credit conditions (low interest rates, or, "easy money") in order to spur a strong economy that could favor their reelection. However, such conditions are not necessarily beneficial for longer-term economic and financial stability. Hence, the Fed has long been held responsible for making decisions about interest rates (and the

142 Michael Burke, Trump Compares Federal Reserve to Golfer That Can't Putt as Market Extends, HILL (Dec. 24, 2018), https://thehill.com/homenews/administration/422743-trump-compares-federal-reserve-to-golfer-that-cant-putt-as-market [https://perma.cc/9NPX5KP3].

143 Press Release, Fed. Reserve, Decisions Regarding Monetary Policy Implementation (Jan. 30, 2019), https://www.federalreserve.gov/monetarypolicy/files/monetary20190130a1.pdf [https://perma.cc/5AKM-X6EN]; see also Nick Timiraos, Fed Signals Hold on Rate Increases, WaLl ST. J. (Jan. 30, 2019), https://www.wsj.com/articles/fed-leaves-rates-unchanged-signals-pause-on-future-increases-11548874931 [https://perma.cc/Q3QCSD9M]; Greg Ip, The Fed's Mysterious Pause, WaLl ST. J. (Jan. 30, 2019), https://www.wsj.com/articles/the-feds-mysterious-pause11548893175? mod=djem10point [https://perma.cc/M6ZU-CUEB].

144 Jerome Powell, Chairman, Fed. Reserve Sys., Address at the Federal Open Market Committee Meeting 2 (Dec. 19, 2018), https://www.federalreserve.gov/mediacenter/files/FOMCpresconf20181219.pdf [https://perma.cc/F6VM-GWL8]; Nick Timiraos, Fed Raises Rates, but Signals Slightly Milder Path of Future Increases, WALL ST. J. (Dec. 19, 2018), https://www.wsj.com/articles/fed-raises-rates-but-signals-slightly-milderpath-of-future-increases-11545246216 [https://perma.cc/QZ7J-6WMZ]. 
money supply) independent from political pressure. ${ }^{145}$ Indeed, precisely as former Federal Reserve Chairman Bill McChesney Martin remarked in a 1955 speech, the Fed's role is to act as "the chaperone who has ordered the punch bowl removed just when the party was really warming up." 146

To sum up: over the past several years there has been a subtle-but critical — change in the way that financial (de)regulation is effectuated. While the Obama Administration began a trend of regulating through interpretative guidance, the current administration, led by President Trump, has doubled down on this practice of sub-legal deregulation. As such, executives in the post-crisis era-more so than before-appear to lean on power to drive financial (de)regulation through a combination of interpretive guidance, directing enforcement priorities, making staffing decisions, delaying the implementation of regulatory rules, and creatively signaling to markets.

If the President can alter the force of a regulation, regulatory frameworks will change more often. When Congress drives regulation, the two-house system ensures that change happens gradually and deliberatively. The President, more so than Congress, is likely to respond more joltingly to market bumps and euphoria. In short, presidentially driven regulation and deregulation is pro-cyclical-it stands to reinforce the current phase of the business and financial cycles. ${ }^{147}$ As such, the chief consequence of presidentially driven (de)regulation

145 Federal Reserve Act, Pub. L. No. 63-43, § 11, 38 Stat. 251, 261-63 (1913).

146 William McChesney Martin, Jr., Chairman, Fed. Reserve Sys. Bd. of Governors, Address before the New York Group of the Investment Bankers Association of America 12 (Oct. 19, 1955), https://fraser.stlouisfed.org/title/statements-speeches-william-mcchesney-martin-jr-448/address-new-

york-group-investment-bankers-association-america-7800 [https://perma.cc/TX3Q-DR5G].

147 See Raghuram G. Rajan, The Credit Crisis and Cycle-Proof Regulation, 91 FED. RES. BANK ST. LouIs REV. 397, 400 (2009) (noting that "faith in draconian regulation is strongest at the bottom of the cycle-when there is little need for participants to be regulated," but in contrast "the misconception that markets will take care of themselves is most widespread at the top of the cycle-the point of maximum danger to the system"). 
is that the pendulum of financial regulation will swing more often. And the financial cycle will quite likely follow.

\section{FROM REGULATORY CYCLES, TO FINANCIAL CYCLES}

This Part explores some economic dangers that may follow from the phenomenon described in Part III. Drawing from the law and finance literature on financial cycles, this Part suggests that the regulatory cycle can have direct and adverse feedback effects on the financial cycle, and in turn, on the real economy.

\section{A. Feedback Loops: An Overview}

Until this point, this Article has described various ways in which the President can or has dialed back financial regulation. To see how such tactics stand to increase the frequency of financial cycles, some basic background is required. The story starts with debt. Credit is central to our economy. As renowned hedge fund manager Ray Dalio has explained in his comprehensive volume on debt crises, "[c]redit is the giving of buying power. This buying power is granted in exchange for a promise to pay it back, which is debt." 148 Credit thus drives spending and investment, which in turn drives GDP and growth.

Credit flows in cycles. During an upswing in the credit (also known as the "financial") cycle, the availability of credit expands along with debt-fueled spending, which increases asset prices, as well as productivity and employment. ${ }^{149}$ The tide eventually turns, and the availability of credit contracts-

148 DALIO, supra note 4, at 9; see also Borio, supra note 4; Marco Terrones et al., Understanding Financial Cycles, Vox EU (July 17, 2011), https://voxeu.org/article/understanding-financial-cycles-0 [https://perma.cc/X8VP-ZT6E].

149 During these upswings, "lending supports spending and investment, which in turn supports incomes and asset prices; increased incomes and asset prices support further borrowing and spending on goods and financial assets. The borrowing essentially lifts spending and incomes above the consistent productivity growth of the economy." DALIO, supra note 4, at 11 . 
along with, again, spending, productivity, and employment. ${ }^{150}$ There are knock-on effects throughout the financial system that follow, because when borrowers can no longer service their debts to lending institutions, the government must intervene and (usually) will support the institutions that are most exposed to depositors or interconnected with the rest of the financial system. ${ }^{151}$ The steeper and more rapid the upswing, the more painful the burst will be, and, hence, the economic downturn that will follow. And when credit is scarce after an economic downturn, a recession or depression can occur. The frequency with which these cycles come and go depends on how much credit is available and how debt is repaid. A loose supply of credit is what fuels an upswing, while tightened lending standards trigger the peak of the cycle and its turning point. ${ }^{152}$

Historically, short-term credit cycles occur around every seven to fifteen years. ${ }^{153}$ But presidentially driven (de)regulation could speed that process up. This is true especially where bank regulation is concerned. Much of that body of regulation creates incentives for financial institutions to make loans to the businesses and households of the real economy. If the President has the levers to relax and tighten such regulations, banks' willingness to lend could change quickly-and, accordingly, the supply of credit would tick up and down. This suggests that the easier it is for a President to tighten and loosen bank regulation, the more rapid and frequent credit cycles could become.

Ultimately, a higher frequency and magnitude of credit cycles would create a more volatile financial system, and this kind of volatility can have a high social cost. Financial cycles end with busts or crashes, which are followed by periods of

150 This happens "[w]hen the costs of debt service become greater than the amount that can be borrowed to finance spending." Id.

151 See id.

152 See id.

153 See id. at 14-16; see also How the Economic Machine Works, BRIDGEWATER, https://www.bridgewater.com/how-the-economic-machineworks [https://perma.cc/RJ38-65B9] (last visited May 25, 2020) (discussing the duration of cycles). 
economic recovery. Crashes tend to create significant macroeconomic pain as the supply of credit contracts. ${ }^{154}$ It follows that the more cycles an economy has, the more busts it has too, and therefore the more regular are the periods of recovery. Presidential regulation and deregulation would thus work at cross-purposes to financial policymakers' goal of a smooth financial cycle. ${ }^{155}$

There is also a slew of unintended consequences that follow from the inevitable central bank interventions that respond to a bust. In particular, monetary policy has distributive consequences that are often unforeseen. For one example, a prolonged period of low interest rates from 2008-16, established by the Federal Reserve in a bona fide effort to stimulate the economy, had resulted in higher asset prices. ${ }^{156}$ Because investors of financial assets tend to be among the "haves," some conjecture that one indirect result of monetary policy can be an increase in income inequality. ${ }^{157}$ Of course, this kind of macroeconomic pain and growing inequality, is precisely the kind of environment that sparks public antipathy toward financial markets.

154 See John Irons, Econ. Policy Inst., Economic Scarring: The LONG-TERM IMPACTS OF THE RECESSION (2009), https://www.epi.org/files/page/-/img/110209scarring.pdf [https://perma.cc/QK6T-ZMJP]. As Morgan Ricks details in his book The Money Problem, the credit crunch experienced in the several years following the crisis resulted in decreased output and higher unemployment. MORGAN Ricks, The Money Problem (2016).

155 Precisely as Mark Brunnermeier and his co-authors point out in their discussion of the financial cycle, financial crashes are not "random[ as a result of a bad institution failing and then the failure becoming systemic. In reality, crashes follow booms." MARK BRUnNeRMEIER ET AL., THE Fundamental Principles of Financial Regulation xvi (2009) (emphasis added).

156 See Mikael Juselius et al., Monetary Policy, the Financial Cycle and Ultra-Low Interest Rates (Bank for Int'l Settlements, Working Paper No. 569, 2016), https://papers.ssrn.com/sol3/papers.cfm?abstract_id=2811107 [https://perma.cc/3EYM-QE7E].

157 See, e.g., David Wessel, Director, Hutchins Ctr. on Fiscal and Monetary Policy, Did the Fed's Quantitative Easing Make Inequality Worse? (June 1, 2015), https://www.brookings.edu/wp-content/uploads/2015/05/20150601_quantitative_easing_inequality_transcript.pdf [https://perma.cc/G8F3-TYTK]. 
The public unrest that results completes the circle. It will spur on more presidentially driven regulation in the first instance, and that regulatory fervor will then sow the seeds for presidentially driven deregulation to follow.

\section{B. Feedback Loops: The Details}

The discussion above sketches out a theory that presidentially driven (de)regulation will speed and sharpen regulatory cycles which will, in turn, amplify the frequency and magnitude of the credit cycle. What follows offers some more detail on this prediction. This Section focuses in particular on the specific way that presidentially driven deregulation can make the upswings of the credit cycle steeper and quicker, precipitate the tipping point, and then generate the kind of uncertainty that makes the descent down the credit cycle faster. It also points to the ways in which presidentially driven (de)regulation might prolong the recovery phase.

First, leverage builds up in the system. Presidentially driven deregulation of the kind discussed above not only loosens lending standards-for example, by backing off the leveraged lending guidance ${ }^{158}$ _ but it can also signal a more favorable attitude toward institutions' use of leverage to fund themselves. In fact, this is precisely what happened between 2017 and 2019. Leveraged lending from banks increased significantly. ${ }^{159}$ Relatedly, debt governance relaxed, which is to say that more lending institutions inserted "covenant lite" arrangements, which borrowers accepted. 160 Additionally,

158 See Semiannual Monetary Policy Report to the Congress: Hearing Before H. Comm. on Fin. Servs., 115th Cong. (2018) (statement of Jerome Powell, Chairman, Federal Reserve System).

159 See Fed Warns Over Leveraged Lending As Banks Chase Riskier Deals, AM. BANKER (Oct. 24, 2018), https://www.americanbanker.com/articles/fed-warns-over-leveraged-lending-as-banks-chase-riskier-deals [https://perma.cc/K7BX-HER6]; Tirupam Goel, The Rise of Leveraged Loans: A Risky Resurgence?, BIS Q. REV., Sept. 2018, at 10.

160 See Tim Cross, Covenant-Lite Credits Continue to Dominate U.S. Leveraged Loan Market, ForBES (Feb. 8, 2018), https://www.forbes.com/sites/spleverage/2018/02/08/covenant-lite-creditscontinue-to-dominate-u-s-leveraged-loan-market/\#6b4288b14400 [https://perma.cc/A84J-FFS4]. 
housing lenders like Fannie Mae and Freddie Mac relaxed their underwriting standards, acting on the perception that laxer practices are acceptable. ${ }^{161}$ As a result, both corporate debt and household debt increased significantly. ${ }^{162}$

Debt growth, of itself, does not necessarily push up the debt cycle or lead to a debt crisis. So long as businesses and households can service their debt (which they can if GDP and incomes grow commensurate with outstanding debt), the economy stays level. Problems do emerge, however, when borrowers cannot service the debt that they have. ${ }^{163}$ When the cost of servicing debt outstrips what can be borrowed to finance spending, a tipping point is reached: the cycle will reverse. ${ }^{164}$

The transition from upswing to downswing can be hastened by presidentially driven (de)regulation insofar as it creates and builds uncertainty. Court challenges, for instance, undermine the stability of deregulatory initiatives overall. ${ }^{165}$ According to one academic study in which researchers developed an "economic policy uncertainty index," uncertainty about economic policy was at an all-time high in $2018 .{ }^{166} \mathrm{It}$

161 See Ip, supra note 81.

162 See Sam Goldfarb \& Rachel Louise Ensign, Corporate Debt Is Reaching Record Levels, WALL ST. J. (Dec. 29, 2018), https://www.wsj.com/articles/corporate-debt-is-reaching-record-levels11546099201 [https://perma.cc/UQD4-M5KX] (noting that corporate debt has reached forty-six percent of GDP, which is a record high).

163 See DALIO, supra note 4; see also Ray Dalio, To Help Put Recent Economic \& Market Moves in Perspective, LinkEDIN (Dec. 26, 2018), https://www.linkedin.com/pulse/help-put-recent-economic-market-movesperspective-ray-dalio [https://perma.cc/84EM-P3YF] ("[I]f debt growth is at rates that finance spending rates that do not produce the cash flows to pay for debt service, it will be unsustainable and big changes need to occur."). As an aside: savings, here, are important as a buffer against unsustainable debt growth. This is because "the equilibrium rate of debt growth is that which is in line with the growth in income that is required to service the debt," but "because incomes are volatile" savings are important-both for households and the government. $I d$.

164 DALIO, supra note 4 , at 11.

165 Raso, supra note 122; Opinion, supra note 121.

166 Jon Hilsenrath, Under Trump, a Strong Economy but Murky Policy Outlook, WALL ST. J. (Apr. 1, 2018), https:/www.wsj.com/articles/under- 
may well be that the degree of legal challenge to the President's deregulatory efforts have contributed to this general feeling of uncertainty.

The uncertainty created by presidentially driven regulation following a bust can then quicken the slide down the credit cycle. Economists from Keynes to Bernanke have agreed that uncertainty affects economic behavior and, specifically, that it can prompt contractions in economic activity on both demand and supply sides. ${ }^{167}$ On the supply side, there is substantial evidence that lending institutions hoarded liquidity or deleveraged after the 2008 financial crisis. ${ }^{168}$ Professor Paul Mahoney has specifically documented a link between the uncertainty of post-crisis regulation and banks' decision to pull back from lending. 169

Borrowers' ability to competitively "demand" (i.e., access) credit can also be affected by uncertainty. According to Keynes, uncertainty can lead to a reduction in productivity and employment. ${ }^{170}$ Bernanke theorized that declines in income and cash flows (which follow from dips in employment and GDP), will reduce the creditworthiness of household

trump-a-strong-economy-but-murky-policy-outlook-1522587600 [https://perma.cc/T8V2-QHYD].

167 See Fernando J. Cardim de Carvalho, Keynes on Probability, Uncertainty, and Decision Making 11 J. Post KeYnesian Econ. 66 (1988); Ben S. Bernanke, Irreversibility, Uncertainty, and Cyclical Investment, 98 Q.J. ECON. 85 (1983).

168 See, e.g., Jose Berrospide, Bank Liquidity Hoarding and the Financial Crisis: An Empirical Evaluation (Fed. Reserve Bd., Fin. \& Econ. Discussion Series, Working Paper No. 2013-03, 2012), https://www.federalreserve.gov/pubs/feds/2013/201303/201303pap.pdf [https://perma.cc/8QLHWFKR] (noting that liquidity hoarding directly reduces the availability of bank credit).

169 Paul G. Mahoney, The Regulatory Effect: Did Regulatory Change Slow Credit Growth after the Great Depression and Great Recession? (U. Va. Law Sch. Law \& Econ. Paper Series, Working Paper No. 2019-12, 2019), https://ssrn.com/abstract=3406849 [https://perma.cc/AB9D-MFNR].

170 Eirini Petratou, Decision-making and Keynesian Uncertainty in Financial Markets: Brexit as a Case Study 3 (unpublished manuscript) (on file with author). 
borrowers-limiting their access to credit. ${ }^{171}$ The fact that less access to credit further reduces creditworthiness is, in effect, a negative loop, which has become known as the "financial accelerator model."172

Problematically, without a steady supply of credit, an economy simply cannot recover from a downturn. ${ }^{173}$ Specifically, as research from the IMF describes: "Recoveries that occur in the absence of credit growth are often dubbed miracles and named after mythical creatures." 174 This can be stated another way. Credit feeds demand for goods and services, and demand sets the appetite and pace for investment in human capital, and hence, productivity. Again, economic research has borne out that healthy productivity growth is tied to the resilience

171 Ben Bernanke et al., The Financial Accelerator and the Flight to Quality, 78 REV. ECON. \& STAT. 1 (1996).

172 See id. at 1 . Demand and supply may be closely linked. According to Fed economists Benigno and Fornaro's "Keynesian growth model," a low cost of credit will also support investment spending and increase the profitability of investing in future production (which, in turn, leads to higher production). See Gianluca Benigno \& Luca Fornaro, The Keynesian Growth Approach to Macroeconomic Policy and Productivity, FED. REs. BANK N.Y.: LIBERTY ST. ECON. (Apr. 1, 2019), https://libertystreeteconomics.newyorkfed.org/2019/04/the-keynesian-growth-approach-to-macroeconomic-policyand-productivity.html [https://perma.cc/8NW6-NTHM]. Higher production leads to higher household expected future income, and therefore higher consumption. See id. (noting that a slowdown in the growth rate of labor productivity lowers households' expected future income and thereby restrains current consumptions).

173 See, e.g., Skinner, supra note 5; see also U.S. DEP'T OF TrEasurY, supra note 131 ("The availability of bank credit to consumers and business in various segments of the economy has been restrained and is growing slowly."). It is agreed by politicians in both parties, as well as among financial experts, that "[i]f businesses and households do not have access to credit, they will be unable to make investments that foster economic expansion." Cindy M. Vojtech, Post-Crisis Lending by Large Bank Holding Companies, BoArd of Governors FED. Res. Sys.: FEDS Notes (July 6, 2017), https://www.federalreserve.gov/econres/notes/feds-notes/post-crisis-lending-by-large-bank-holding-companies-20170706.htm [https://perma.cc/6A4P-C9SH].

174 Abdul G. Abiad et al., Creditless Recoveries, (Int'l Monetary Fund, Working Paper No. 11/58, 2011), https://papers.ssrn.com/sol3/papers.cfm?abstract_id=1792224 [https://perma.cc/2ZKY-F3QZ]. 
of the economy. ${ }^{175}$ Accordingly, where presidentially driven regulation exacerbates uncertainty, it creates a drag on the recovery phase of the credit cycle as well.

\section{CONCLUSION}

This Article has shed light on the way in which the President has more tools than ever before to drive financial regulation and deregulation. These methods enable Presidents to exert the kind of pressure necessary to tighten or loosen constraints on the financial system. As a result, the pendulum of financial regulation is now poised to swing more frequently than in pre-2008 crisis years. The Article sketched out the problem that follows from compressed regulatory cycles: more frequent credit cycles-which means a financial system that experiences a greater number of booms and busts. With these financial ups and downs, the real economy must weather more periods of high unemployment and sluggish GDP growth.

So what can be done to minimize presidentially driven (de)regulation? A few options might be possible. For one, some scholars have explored various forms of safety valves, or automatic checks on crisis-induced legislation. Professor Roberta Romano, for example, has proposed automatic sunsets for financial legislation. ${ }^{176}$ Installing sunsets into financial regulatory rules-or mandating periodic re-evaluations-might temper the political desire to deregulate the financial system wholesale, with whatever tools available.

A second possibility is to expand requirements for cost-benefit analyses in financial regulatory decision making. Such an expansion could include a requirement to engage in such analyses in connection with any regulatory or deregulatory initiative which would accomplish a tightening or loosening, even if no rules or laws are changed. Such a reform would capture the sub-legal (de)regulation that has been the subject of this Article.

Finally, it may be time to reexamine or impose new limits on congressional delegations to financial regulatory agencies.

175 See Benigno \& Fornaro, supra note 172.

176 See Romano, supra note 6, at 1600. 
Presidential (de)regulation may be exacerbated by broad delegations of power to the regulatory agencies. Notably, the rise of executive-driven (de)regulation has coincided with perhaps the broadest financial regulatory statute in history. The DoddFrank Act contained 390 mandatory rulemakings ${ }^{177}$ and numerous other grants of discretionary rulemaking authority. ${ }^{178}$ That delegated authority allowed for the creation of broadly worded rules. In some cases, broad rules promulgated under Dodd-Frank were meant to thwart financial institutions' ability to arbitrage or "game" the regulatory system, but in others, the breadth was designed to keep agencies' enforcement options open in light of the changing nature of financial risk. ${ }^{179}$ However, just as this breadth gave the prior administration considerable latitude to level up regulation as needed, it now gives the current administration a wide berth to level it down.

177 Davis Polk \& Wardwell LLP, Dodd-Frank Progress Report:

$\begin{array}{lllll}\text { THIRD } & \text { QUARTER } & 2015 & 2 & \text { (2015), } \\ \text { https://www.da- }\end{array}$
vispolk.com/files/Q32015_Dodd.Frank_.Progress.Report.pdf [https://perma.cc/F7S2-BDSK].

178 For one example of such delegated discretionary authority, see Dodd-Frank Act, Pub. L. No. 111-203, § 1022, 124 Stat 1376, 1980-1985 (2010) (delegating authority to the CFPB to promulgate rules under a variety of statutory provisions). Additionally, although FSOC is not a rulemaking body it can, under section 120 of Dodd-Frank, recommend that other agencies make rules. Dodd-Frank Act $§ 120$.

179 As Coffee notes,

the Dodd-Frank Act depends upon administrative implementation to a far greater degree than did SOX because Congress simply could not specify in detail the proper implementation with respect to capital adequacy, liquidity ratios, over-the-counter (OTC) derivatives, and similar complex financial issues applicable mainly to large financial institutions.

Coffee, supra note 6, at 1028. 